\title{
Taxing Multinationals: A Fundamental Shift Is Under Way
}

For too long, international institutions have failed to deal with one of the most toxic aspects of globalisation: tax avoidance by multinational corporations. This has reduced governments' abilities to address international challenges such as the global pandemic, climate change, forced migration and rising inequality. It has also taken away a tool to achieve equality and distributive justice and thereby diminished citizens' trust in the social contract.

Shifting profits to tax havens, large companies deprive governments of at least $\$ 240$ billion per year in fiscal revenues. The Global South is disproportionately affected because their revenue sources are more limited, so reliance on corporate tax receipts to fund public services is greater.

In a globalised and digital economy, multinationals operate through centrally managed business models, and their global profits are largely the result of their global operations. Yet current international tax rules, developed nearly a century ago, treat subsidiaries of multinationals as legally independent firms which trade between each other using "arm's length" or normal commercial prices to transfer goods and services.

But such prices are not always easy to find. Many markets are thin and dominated by the same multinationals, who then exploit this system to minimise their tax liability by shifting profits to jurisdictions with low or zero tax rates. This undermines the tax base of countries where real activities occur and, therefore, where the profits have been generated. These rules are also skewed in favour of rich countries because they help multinationals' home countries get the biggest share of tax from global profits. This "transfer pricing" is exacerbated by tax competition to the point that the global average statutory corporate tax rate has fallen by more than half in three decades.

Following widespread public anger at tax avoidance scandals in 2012, the G20 mandated the OECD to establish the G20/OECD Base Erosion and Profit Shifting Project in 2013, aimed at tackling the issue. So far, reform proposals have fallen short of expectations. Comprehensive reforms have been hindered by dominant OECD member governments, which come to negotiations with the misplaced perception that national interest is served by protecting multinationals headquartered in their own countries. This has prevailed over genuine, global public interest.

The negotiating process has nonetheless reached agreement that multinationals should be considered unitary businesses. This means that their worldwide profits should be taxed in line with their real activities in each country and allocated to different jurisdictions, based on a formula according to the key factors that generate profit: employment, sales and assets. Many states in the United States use a similar "formulary apportionment" system to determine their taxable shares of US corporate profits. In 2016, the EU Commission put forward a similar proposal for an EU Common Consolidated Corporate Tax Base, but it has not yet been approved by the European Council.

Formulary apportionment would remove the current artificial incentive for multinationals to shift reported income to low-tax locations. Tax liabilities, instead, would be allocated by measures of their real economic activity in each location. But the proposal currently being negotiated involves applying this to only a small share of a firm's global profits (so-called "residual" rather than "routine" profits) and is mainly directed at mostly US-based highly digitalised multinationals. This is not sufficient to address the problem.

(C) The Author(s) 2021. Open Access: This article is distributed under the terms of the Creative Commons Attribution 4.0 International License (https://creativecommons.org/licenses/by/4.0/).

Open Access funding provided by ZBW - Leibniz Information Centre for Economics. 
Instead, we need a more ambitious and comprehensive reform that replicates the US system at the international level, without distinction between digital and non-digital businesses. This would help to establish a more level playing field, reduce distortions, limit opportunities for tax avoidance, and provide certainty to multinationals and investors. To put an end to harmful tax competition between countries, this system should be supported by a global minimum tax on multinationals so as to reduce the incentive for multinationals to shift profits to tax havens.

Until recently, negotiations on a global minimum tax were benchmarked by the existing US minimum tax on US corporations' foreign earnings (known as "GILTI"), which has a rate of $10.5 \%$. As a result, public discourse centred around a possible minimum tax rate of around $12.5 \%$ (incidentally, the corporate tax rate in Ireland, one of the EU's own tax havens). Such a low minimum tax rate could in fact over time become the global ceiling, in which case the laudable initiative to oblige multinationals to bear their fair share of taxes would end up doing the opposite.

Negotiations do not happen in a vacuum. The global pandemic has forced a fundamental rethink in many countries of the benefits of a race to the bottom in corporate tax rates. The new US administration campaigned on a manifesto to increase corporation tax from $21 \%$ to $28 \%$ and to double the current rate of minimum tax to $21 \%$. The UK government has just announced a plan to raise its main rate of corporation tax from $19 \%$ to $25 \%$ in 2023.

This shift reflects a new understanding of the lack of positive association between corporation tax and investment decisions. The earlier belief that corporation tax cuts could help spur business investment has been contradicted by the reality that corporation tax decreases have failed to provide a step change in the level of capital investment.

This is true in the UK, where the corporation tax rate was cut from $30 \%$ before the global financial crisis to the current rate of $19 \%$; in India, where the base rate was reduced to $22 \%$ from $30 \%$ in 2019; and the US, where the Trump Administration reduced the corporation tax rate from 35\% to $21 \%$ in 2017 . In the case of the US, instead of spurring investment, the rate cut mainly ended up funding dividend payments and stock buybacks.

This lack of effect on investment should not come as a surprise, as corporate taxation is a tax on pure profits - also known as economic rents - and therefore, lowering or raising the rate has little effect on economic activity. Rents have been on the rise over the last decades, notably in the US, but also globally as a result of increased market concentration and monopoly/monopsony power. These have in turn been triggered by gaps in access to technology (fuelled by intellectual property rights) and a series of benefits and privileges not available to smaller firms. The increase of rents suggests that governments should consider progressive corporate taxes, with higher rates on larger firms (especially monopolies/oligopolies) and lower rates on smaller firms in highly competitive sectors.

Tommaso Faccio, Nottingham University Business School, UK; and Independent Commission for the Reform of International Corporate Taxation.

Jayati Ghosh, University of Massachusetts, Amherst, USA; and Independent Commission for the Reform of International Corporate Taxation.
As companies return to profitability post-crisis, this will allow governments to generate revenue without distorting investment. A more progressive corporate tax structure would also address excess profits enabled by crisis conditions, by raising tax revenues from companies that are thriving during the pandemic (such as some pharmaceutical and highly digitalised businesses).

This shift in thinking may make a strong global agreement on an effective minimum tax a possibility and encourage countries to start a virtuous race to the top. If G20 countries were to agree to impose a $25 \%$ minimum corporate tax on the global income of their multinational firms, more than $90 \%$ of worldwide profits would automatically be taxed at $25 \%$ or more.

There is broad evidence of the need for fundamental reform in the international tax system, but it requires political will to move forward. Any outcome in the 2021 international negotiations must be seen as the first step towards creating a genuinely fair international fiscal architecture. 